\title{
Hipnoterapi Teknik Regression Therapy Untuk Menangani Penderita Glossophobia Siswa Sekolah Menengah Pertama
}

\author{
Atrup $^{1}$, Dwi Fatmawati \\ Bimbingan Konseling \\ Universitas Nusantara PGRI Kediri \\ atrup@unpkediri.ac.id
}

\begin{abstract}
Abstrak
Hasil pengamatan di salah satu sekolah menengah pertama di Kota Kediri, menunjukkan hampir di setiap kelas ditemukan siswa yang takut berbicara di depan umum (glossophobia). Hal ini tampak pada ketika ditunjuk untuk menjawab soal mereka memilih diam, atau saat guru memberikan kesempatan bertanya mereka memilih diam dan bertanya kepada teman yang lain. Dikawatirkan siswa yang menderita glossophobia tidak berkembang secara optimal dan berlanjut hingga dewasa. Permasalahan penelitian ini adalah apakah hipnoterapi teknik regression therapy efektif untuk mengatasi glossophobia siswa kelas VII SMP Negeri 3 Kediri?. Penelitian ini menggunakan pendekatan kuantitatif, desain SSD (Single Subject Design) dengan subjek penelitian 2 siswi yang diidentifikasi penderita glossophobia. Penelitian ini dilaksanakan dalam 7 kali pertemuan, 3 kali fase baseline dan 4 kali fase intervensi. Setiap pertemuan di fase intervensi diterapkan teknik regression therapy. Setelah kegiatan ini selesai, subjek diminta untuk mengisi angket glossophobia dengan tujuan untuk mengetahui seberapa efektif pemberian dalam menurunkan penderita glossophobia. Penelitian ini menyimpulkan bahwa hipnoterapi teknik regression therapy efektif untuk mengatasi penderita glossophobia siswa. Ini dibuktikan dengan trend dari grafik kedua subjek menurun dan menunjukkan yang perubahan positif. Berdasarkan simpulan tersebut, disarankan: (1) guru BK dapat menerapkan hipnoterapi teknik regression therapy untuk mengatasi glossophobia siswa, dan (2) bagi peneliti lanjutan disarankan untuk meneliti masalah ini dengan jangkauan wilayah penelitian yang lebih luas.
\end{abstract}

Kata kunci: hipnoterapi, teknik regression therapy, glossophobia.

\section{PENDAHULUAN}

Pendapat Miler (dalam Daryanto, 2011) komunikasi sebagai situasi yang memungkinkan suatu sumber mentransmisikan suatu pesan kepada seorang penerima dengan disadari untuk mempengaruhi perilaku penerima. Dalam lingkup pendidikan formal, siswa dituntut aktif untuk berkomunikasi, baik dengan teman maupun guru, dalam seting resmi seperti persentasi maupun rapat ataupun dalam seting santai seperti berbincang dengan teman. Namun sayangnya, masih banyak ditemui siswa yang enggan untuk berkomunikasi atau berbicara ketika di depan umum. Dari hasil pengamatan di Sekolah Menengah Pertama Negeri (SMPN) 3 Kota Kediri, hampir setiap kelas terdapat siswa yang takut untuk berbicara di depan umum. Seperti, ketika ditunjuk guru untuk maju kedepan menjawab soal yang diberikan, siswa lebih memilih untuk tetap diam dan tidak mau menjawab, kemudian ketika ada seminar atau penyuluhan pada sesi tanya jawab biasanya siswa enggan untuk bertanya. Di sini, siswa yang enggan atau takut untuk berbicara di depan umum biasa disebut dengan glossophobia. 
Anxiet Disorders Association of Canadadalam Werhadiantiwi (2014) menyatakan bahwa glossophobia merupakan salah satu phobia sosial dimana penderita memiliki ketakutan pada situasi sosial yang dapat menyebabkan masalah dalam sekolah atau kehidupan sosial lainnya.Glossophobia ini hanya mempengaruhi kemampuan berbicara, bukan yang lain. Penderita glossophobia bisa saja menari atau menyanyi di depan umum, hanya saja mereka kesulitan saat harus berbicara di depan umum. Ketakutan berbicara di depan umum atau glossophobia terjadi karena pikiran bawah sadar mengambil alih kesadaran dan menganggap situasi sosial sebagai sebuah ancaman sehingga tubuh akan merespon dengan melawan atau lari menghindar. Menurut Wallechinsky dalam Fatma (2012), "Berbicara di depan umum merupakan ketakutan yang tertinggi dari 10 ketakutan yang dialami oleh manusia". Dari penelitian tersebut dapat disimpulkan bahwa glossophobia memang dapat diderita oleh siapa saja termasuk siswa, dimana apabila permasalahan tersebut tidak segera dipecahkan akan mengakibatkan hal yang fatal bagi siswa karena ketika siswa merasa kesulitan untuk mengatakan apa yang diinginkan atau pendapat apa yang dimiliki, perkembangan siswa akan terganggu.Untuk mengurangi ketakutan berbicara di depan umum yang dialami siswa, pihak sekolah telah melaksanakan berbagai cara. Mulai dari member pertanyaan dan menunjuk siswa yang selalu diam, memberikan tugas kelompok yang hasilnya harus dipresentasikan di depan kelas hingga memberikan motivasi pada siswa.

Namun berbagai upaya tersebut dirasa belum cukup untuk mengatasi glossophobia yang dirasakan siswa. Oleh karena itu, dalam pendidikan formal khususnya Guru Bimbingan dan Konseling (BK) harus berusaha ekstra dalam memberikan motivasi untuk siswa. Dalam menangani,tentunya Guru BK dapat menggunakan berbagai teknik dan keterampilan yang dimilikinya. Adapun strategi yang digunakan dalam mengurangi ketakutan berbicara di depan umum siswa diantaranya adalah dengan hipnoterapi. Gunawan (2012a) menyatakan hipnoterapi adalah aplikasi hipnosis dalam menyembuhkan masalah mental dan fisik (psikosomatis). Hipnoterapi merupakan proses terapi yang dilakukan ketika klien atau konseli telah memasuki kondisi relaksasi atau santai. Jadi dalam strategi ini, Guru BK membantu konseli untuk berada dalam kondisi rileks dan nyaman untuk membantu mengatasi glossophobia siswa. Dalam dunia BK, hipnoterapi telah umum digunakan dalam memecahkan berbagai masalah, seperti penelitian yang dilakukan oleh Atrup (2015; 2014), Atrup, dkk. (2016a; 2016b; 2016c; 2016d) berusaha mengembangan model konseling dengan mengintegrasikan hipnoterapi untuk pemecahan masalah konseli. Berbagai metode juga banyak digunakan dalam mengatasi masalah glossophobia siswa, seperti penelitian Werhadiantiwi (2014) yang berjudul Penerapan Konseling Kelompok Dengan Teknik Self Instruction Untuk Mengurangi Tingkat Glossophobia Pada Siswa Kelas XI IPS-1 Di SMA Negeri 1 Gedangan. Ratnasari (2012) meneliti Penggunaan Konseling Kelompok Dengan Kombinasi Strategi Reframing dan Self Modelling Untuk Menurunkan Tingkat Kecemasan Berbicara Di Depan Umum. Nuryono (2016) meneliti Penerapan Konseling Naratif Untuk Mengurangi Tingkat Glossophobia Siswa Kelas X SMAN 13 Surabaya. Oleh karena masalah glossophobia perlu mendapatkan perhatian yang lebih, Guru BK harus cermat dalam memilih dan menggunakan teknik dalam konseling guna tercapai tujuan yang ditentukan. Adapun teknik yang dapat diterapkan adalah teknik regression therapy, Gunawan (2012b) menyatakan teknik regression therapy atau age regression therapy adalah teknik yang digunakan untuk membawa klien mundur ke masa lampau guna menemukan akar 
masalah dan melakukan terapi. Penderita glossophobia diduga berkaitan dengan kehidupan masa lalunya. Itu sebabnya dirasa sesuai dalam penelitian ini dimaksudkan untuk menguji efektivitas penggunaan teknik regression therapy untuk menangani penderita glossophobia siswa.

Kata "phobia" berasal dari istilah Yunani "phobos" yang berarti lari (fight), takut dan panik (panic-fear), takut hebat (terror). Gangguan fobia adalah rasa takut yang persisten terhadap objek atau situasi dan rasa takut ini tidak sebanding dengan ancamannya. Nevid (2003) menyatakan gangguan fobia adalah rasa takut yang persisten terhadap objek atau situasi dan rasa takut ini tidak sebanding dengan ancamannya. Pada gangguan fobia, ketakutan yang dialami jauh melebihi penilaian tentang bahaya yang ada. Webster's New World Dictionary (dalam Hunter, 2015), definisi dari fobia adalah rasa takut yang tidak rasional, berlebihan, dan persisten terhadap hal-hal atau situasi tertentu. Kartono (2000) mendefinisikan phobia sebagai ketakutan atau kecemasan yang abnormal, tidak rasional tidak bisa dikontrol terhadap suatu situasi terhadap objek tertentu. Atkinson dkk. (2005) mengatakan istilah "phobia" berasal dari kata "phobi" yang artinya ketakutan atau kecemasan yang sifatnya tidak rasional, yang diarasakan dan dialami oleh seseorang.

Berdasarkan pengertian diatas, dapat disimpulkan bahwa fobia adalah rasa takut yang berlebihan kepada suatu hal atau fenomena yang membuat hidup seseorang yang menderitanya terhambat. Berikut ini adalah tiga tipe fobia berdasarkan sistem DSM (Diagnostic and Statistical Manual of Mental Disorders) (dalam Nevid, 2003), yaitu fobia spesifik, fobia sosial, dan agorafobia.

Fobia spesifik adalah ketakutan yang berlebihan dan persisten terhadap objek atau situasi spesifik, seperti: Acrophobia: takut terhadap ketinggian, bahkan hanya setinggi 2 meter sudah cukup menakutkan bagi penderita fobia ini. Claustrophobia: takut terhadap tempat tertutup atau terkunci sehingga orang dengan fobia jenis ini sering berada di taman atau di lapangan olahraga bersama teman-temannya. Fobia binatang: takut terhadap binatang tertentu seperti tikus, ular, atau binatang-binatang menjijikkan. Fobia dengan benda-benda tertentu: seperti jarum suntik (bukan sakitnya yang mereka takuti, tetapi jarumnya), pisau, benda-benda elektronik, atau benda-benda lain.

Fobia sosial adalah ketakutan yang intens terhadap situasi sosial atau ramai sehingga mereka mungkin sama sekali menghindarinya, atau menghadapinya tetapi dengan distres yang amat berkecamuk. Penderita fobia sosial mengalami ketakutan terhadap situasi sosial seperti datang ke pesta, pertemuanpertemuan sosial, bahkan presentasi untuk ujian. Fobia sosial yang mendasar adalah ketakutan berlebihan terhadap evaluasi negatif dari orang lain, dalam artian mereka takut dinilai jelek oleh orang lain. Mungkin mereka merasa seakan-akan ribuan pasang mata sedang memperhatikan dengan teliti setiap gerak yang mereka lakukan. Contoh umum untuk fobia jenis ini adalah: demam panggung yang berlebihan, kecemasan berbicara di forum yang berlebihan, bahkan dihadapan orang-orang terdekat sekalipun, kecemasan meminta sesuatu, seperti memesan makanan di rumah makan karena takut pelayan atau teman menertawai makanan yang mereka pesan, ketakutan bertemu dengan orang baru, hal ini menyebabkan penderita tidak berkembang dalam hal sosial. Fobia jenis ini menyebabkan penurunan kualitas hidup penderitanya, seperti kualitas untuk mencapai sasaran pendidikan, maju dalam 
karier, atau bertahan dalam pekerjaan yang membutuhkan interaksi dengan orang lain secara langsung. Sekali fobia sosial tercipta, maka akan berlanjut secara kronis sepanjang hidup.

Agorafobia secara harfiah diartikan sebagai "takut kepada pasar", yang sugestif untuk ketakutan berada di tempat-tempat terbuka dan ramai. Agorafobia melibatkan ketakutan terhadap tempat-tempat atau situasi-situasi yang memberi kesulitan bagi mereka untuk meminta bantuan ketika ada suatu problem yang menimpa mereka atau orang lain. Orang-orang dengan agorafobia takut untuk pergi berbelanja di toko-toko yang penuh sesak, bersempit-sempitan di bus, dan lain-lain yang kira-kira membuat mereka sulit meminta pertolongan.

Glossophobia menurut Hancock (dalam Khan, dkk., 2015) berasal dari bahasa Yunani glossa yang berarti lidah dan phobos berarti rasa takut atau ketakutan. Pengertian glossophobia dalam Wikipedia adalah sebuah rasa takut yang tidak normal ketika berbicara atau mencoba untuk berbicara di hadapan publik. Counselling Center, University of Wisconsin Stout dalam Werhadiantiwi (2014) mendefinisikan ketakutan berbicara di depan umum (glossophobia) adalah suatu hal yang melibatkan rasa takut untuk dinilai atau dievaluasi oleh orang lain. Ketakutan ini sering disertai dengan berbagai reaksi fisik dan emosional yang signifikan dan dapat mengganggu kemampuan seseorang untuk berhasil memberikan pidato atau presentasi.

Dari pengertian diatas dapat ditarik kesimpulan bahwa glossophobia adalah ketakutan ketika berbicara di depan umum, yang membuat seseorang bereaksi fisik dan emosional. Anxiet Disorders Association of Canada (dalam Werhadiantiwi, 2014) mengemukakan bahwa ketakutan berbicara di depan umum tergolong dalam jenis fobia sosial. Takut berbicara di depan umum mempengaruhi pederita secara fisiologis, misalnya, mulut terasa kering, tekanan darah meningkat, wajah memerah, keluar keringat dingin, napas tidak teratur, dan emosional, karena mereka merasa takut atau malu terlihat bodoh. Orang yang mengalami ketakutan berbicara ini cenderung terlihat bingung ketika di hadapan orang banyak. Suara mereka menjadi lemah dan tubuh mereka mulai gemetar.

Khusner (dalam Khan, dkk., 2015), takut berbicara di depan umum mempengaruhi pembicara secara fisiologis, misalnya, mulut kering, peningkatan tekanan darah, wajah memerah, berkeringat, napas tidak teratur, dan emosional, karena mereka takut akan dihina dan tampak bodoh. Sedangkan Beatty dkk. (dalam Tse, 2012), ketakutan berbicara di depan umum mungkin berasal dari berbagai sumber, seperti keterampilan sebagai pembicara, kefasihan dalam bahasa, kecenderungan emosional, dan karakteristik situasi berbicara di depan umum itu sendiri.

Ada beberapa alasan seseorang memiliki rasa takut berbicara di depan umum, antara lain: (1) pengalaman masa lalu yang negatif (trauma), Freud (dalam Corey, 2013) mengemukakan terdapat lima fase dalam kehidupan yang mempengaruhi keberlangsungan hidup seseorang di masa depan, kelima fase tersebut disebut dengan perkembangan psikoseksual, yang terdiri dari fase oral, fase anal, fase phalik, fase laten, dan fase genital. Apabila salah satu fase tersebut tidak berkembang secara optimal akan mengakibatkan permasalahan dalam diri seseorang. Seseorang yang menderita glossophobia ini memiliki kemungkinan bahwa terdapat permasalahan 
pada fase laten dimana pada fase tersebut tidak berkembang secara optimal. Dalam keadaan normal, fase laten terjadi ketika usia 5-12 tahun, dimana proses sosialisasi anak mulai meluas dan membangun hubungan dengan orang lain. Namun, ketika anak tidak mengoptimalkan kemampuan bersosialisasinya mengakibatkan ia lebih senang untuk menyendiri, sehingga menyebabkan ia memiliki keyakinan yang negatif ketika harus berbicara di depan umum. Trauma yang dialami dimasa lampau juga dapat mempengaruhi ketakutan seseorang untuk berbicara di depan umum. Misalnya ketika dulu saat di sekolah dasar ia pernah melakukan persentasi, namun hasil yang didapat tidak sesuai dengan apa yang dibayangkan. Guru terlalu keras memarahi dan menyalahkan pada hasil yang dipersentasikan, hal itulah yang dapat menyebabkan seseorang mengalami ketakutan berbicara di depan umum karena ia takut malu atau dinilai tidak mampu oleh orang lain. (2) kurangnya rasa percaya diri atau harga diri, percaya diri merupakan keyakinan individu terhadap dirinya sendiri untuk bertingkah laku, bertanggung jawab atas tindakannya, dan tidak terpengaruh oleh orang lain. Seseorang dengan glossophobia memiliki percaya diri yang rendah, karena ia mudah terpengaruh dengan orang lain. Ketika orang lain menilai dirinya tidak mampu, ia akan terpengaruh dan menyebabkan ia untuk takut ketika harus berbicara di depan umum, (3) Lemahnya kesadaran akan diri sendiri, penderita glossophobia memiliki tingkat kesadaran yang rendah terhadap dirinya sendiri, maksudnya adalah ia tidak mampu mengidentifikasi kelebihan dan kelemahan yang ada pada dirinya, sehingga ia berkeyakinan bahwa tidak ada kelebihan yang ada pada dirinya. Hanya ada perasaan tidak mampu yang ada dalam dirinya, (4) takut membuat kesalahan atau mengatakan hal yang salah, sebelum berbicara di depan umum, penderita sudah merasa takut bahwa nanti ia akan membuat kesalahan atau mengatakan hal yang salah ketika berbicara di depan umum. Pemikiran tersebut membuatnya menjadi semakin tidak yakin dengan apa yang harus diungkapkannya ketika berbicara di depan umum, (5) takut menjadi pusat perhatian, memiliki rasa percaya diri yang rendah, mengakibatkan seseorang takut ketika ia akan dijadikan pusat perhatian, bahkan ketika harus persentasi ia takut akan menjadi pusat perhatian teman satu kelasnya, (7) merasa berada dalam situasi yang asing, meskipun melakukan persentasi di depan kelas, penderita glossophobia merasa asing dengan situasi kelasnya karena ketakutan yang dialami membuatnya tidak yakin dengan semua tindakan yang dilakukan, (8) takut ditertawakan, perasaan takut dinilai oleh orang lain sangat besar dirasakan oleh penderita glossophobia, hal ini menyebabkan ia berfikiran bahwa ketika persentasi ia melakukan kesalahan ia akan ditertawakan oleh orang lain, (9) takut lupa apa yang harus dikatakan, ketika gugup, seseorang wajar tidak sengaja lupa apa yang harus dikatakan, namun penderita glossophobia memiliki ketakutan yang besar, bahkan sebelum ia berbicara di depan umum ia merasa takut jika nanti akan lupa pada apa yang harus dikatakan, dan (10) takut dihakimi, kesalahan yang terjadi ketika berbicara di depan umum membuat penderita takut akan disalahkan, dan dihakimi oleh orang lain.

Menurut Monart dan Kase (dalam Haryanthi, 2012), faktor-faktor yang mempengaruhi individu mengalami 
kecemasan berbicara di depan publik, adalah sebagai berikut: (1) faktor biologis, rasa takut maupun cemas dialami semua orang ketika berhadapan dengan bahaya. Pada saat menghadapi situasi yang membuatnya merasa tidak nyaman, respon fisiologis yang tampak pertama, sistem saraf simpatis mereproduksi dan melepaskan adrenalin yaitu suatu hormon fight (menghadapi) dan flight (menghindari) situasi bahaya. Kedua, detak jantung berdebar dengan kuat, tekanan darah naik, wajah bersemu merah. Ketiga, merasakan adanya sensasi dingin dan gemetar pada tangan dan kaki. Keempat, napas memburu dengan cepat, sulit mengatur pernapasan dan mengalami sakit kepala ringan. Kelima, berkeringat pada sekujur tubuh; (2) faktor pemikiran negatif, pikiran akan memicu respon biologis, sebaliknya adakalanya respon biologis yang menampakkan kecemasan dan pikiran negatif akan menyertainya. Pikiran negatif yang utamanya timbul, pertama bahwa berbicara di depan umum menakutkan. Kedua, pikiran yang terlalu berlebihan terhadap konsekuensi negatif dari suatu situasi sosial. Ketiga, adanya perasaan kurang mampu mengatasi beberapa kesulitan pada situasi sosial. Keempat, fokus terhadap aspek negatif dari suatu situasi dan mengabaikan hal-hal yang positif, (3) faktor perilaku menghindar, respon yang alami saat mengalami kecemasan adalah bagaimana agar dapat lepas dari kondisi tersebut dengan strategi menghindar. Seseorang berusaha menghindari situasi yang membuat tegang tersebut secepat mungkin dan tidak ingin kembali pada situasi yang sama. Ada beberapa perilaku yang muncul terkait dengan kondisi tersebut, yaitu: menghindari situasi yang menakutkan, perilaku cemas yaitu perilaku yang sering tampak dalam situasi berbicara di publik, sering kali dilakukan tanpa disadari bahwa individu sedang merasa cemas seperti tangan di saku, memainkan pulpen, meremas tangan, menyentuh dan memperbaiki tata letak rambut, berbicara cepat, berjalan mondar-mandir, gelisah dan lain-lain, perilaku dengan kompensasi berlebihan, (4) faktor emosional, saat seseorang menunjukkan situasi takut, ia akan mengalami respon fisiologis, kognitif dan perilaku yang menggambarkan situasi tersebut sehingga dirinya sendiri yang mengembangkan rasa takut terhadap situasi tertentu. Individu tersebut cenderung merasakan perasaan cemas, takut, khawatir, merasa tidak mudah menghadapi situasi sosial, tegang, panik, dan gugup menghadapi situasi berbicara di depan umum. Saat individu menghindari situasi berbicara di depan publik tersebut, mereka menyadari implikasinya terhadap karir dan kehidupan sosial. Hal tersebut menyebabkan perasaan depresi, murung, frustasi, putus asa, dan perasaan takut.

Hipnoterapi: teknik regression therapy. Dalam sepuluh tahun terakhir keilmuan hipnosis telah mengalami perkembangan yang pesat, tidak saja dalam bidang terapi akan tetapi telah merambah dalam berbagai bidang seperti pendidikan, konseling, penjualan, komunikasi, politik, kecantikan, membantu proses kelahiran, dan sejenisnya. Gunawan (2012a), menyatakan hipnosis berasal dari kata hypnosis atau hypnotism yang berarti suatu kondisi yang menyerupai tidur yang dapat secara sengaja dilakukan kepada seseorang atau sekelompok orang. Hipnosis dapat juga diartikan sebagai upaya untuk menembus pikiran bawah sadar melalui RAS (Raticular Activating System), atau suatu 
kondisi dimana seseorang mudah untuk diberikan sugesti.

Secara umum, penerapan hipnosis dapat digolongkan ke dalam beberapa hal yakni: (1) hipnosis untuk keperluan hiburan, atau hipnosis panggung sering kali disebut stage hypnosis, (2) hipnosis untuk keperluan pemberdayaan dan terapi, yaitu penerapan hipnosis untuk pemberian sugesti positif, motivasi dan penguatan (reinforcement) dan penyelesaian berbagai masalah psikologis yang bersifat psikosomatis dengan menerapkan berbagai teknik terapi salah satunya diterapkan dalam penelitiannya ini, sering kali disebut hypnotherapy, (3) penerapan hipnosis untuk manajemen rasa sakit, sering kali disebut anodyne awareness, dan (4) hypnoforensic, yaitu penerapan hipnosis untuk memperoleh efek hipnosis.

Prinsip dasar penerapan hipnosis teknik regression therapy dijelaskan Gunawan (2012b), bahwa teknik ini digunakan dengan membawa konseli mundur ke masa lampau guna menemukan akar masalah dan melakukan terapi. Setelah akar masalahnya ditemukan, baru dilakukan terapi. Terdapat empat tahap dalam teknik regression therapy, yaitu tahap persiapan, regresi (mundur ke masa lalu), menangani abreaction dan pembelajaran ulang bawah sadari. (1) tahap persiapan bertujuan untuk menyiapkan klien agar memahami apa yang dimaksud dengan regression therapy, apa yang akan dilakukan saat terapi, dan apa yang diharapkan dari terapi ini, (2) regresi (mundur ke masa lalu) dilakukan secara hati-hati dan saksama dengan menggunakan teknik yang tepat, sesuai dengan tipe sugestibilitas klien. Terapis perlu memperhatikan tingkat kedalaman trance dan mempertahankan klien di kedalaman ini. Klien perlu merasakan kembali pengalamannya (revivification), bukan sekedar melihat atau mengingat masa lalunya, (3) menangani abreaction, terapis perlu bersiap diri dan menyiapkan klien untuk menangani abreaction yang mungkin timbul karena klien mengalami kembali kejadian atau pengalaman yang traumatic. Abreaction adalah release atau pelepasan tekanan psikologis akibat pengalaman traumatik, dan (4) pembelajaran ulang atau manajemen pikiran bawah sadar. Setelah melewati fase ketiga, pikiran bawah sadar klien diedukasi ulang dalam kaitannya dengan pengalaman traumatik yang baru saja dialaminya kembali. Apabila reedukasi ini berhasil dilakukan dengan sempurna, klien akan sembuh atau terbebas dari trauma.

\section{METODE PENELITIAN}

Pendekatan yang digunakan dalam penelitian ini adalah pendekatan kuantitatif (Sugiyono, 2015), ragam penelitian eksperimen dengan desain penelitian single subject design (Sunanto, dkk. 2005; Creswell, 2015). Creswell (2015), single subject research disebut juga ( $N$ of 1 research, small-N designs, applied behavioral analysis, within-subjects comparisons, single case experimental design, atau single-subject research design) melibatkan penelitian terhadap seorang individu tunggal, sebuah dyad, atau sebuah kelompok, observasi selama periode basal, dan pengadministrasian suatu intervensi, yang diikuti oleh observasi lain setelah intervensi tersebut untuk menentukan apakah perlakuan itu mempengaruhi hasilnya. Dalam penelitian ini, peneliti dapat mengambil satu, dua atau tiga orang responden sesuai dengan kebutuhannya. Analisis datanya pun tidak dicari dengan rata-rata namun dianalisis secara menyeluruh antar satu subjek. Sunanto, dkk (2005) desain subyek tunggal 
memfokuskan pada data individu sebagai sampel penelitian.

Penelitian ini menggunakan desain A-B dengan prosedur utama yang ditempuh meliputi pengukuran target behavior pada fase baseline dan setelah trend dan level datanya stabil kemudian intervensi mulai diberikan. Selama fase intervensi target behavior secara kontinyu dilakukan pengukuran sampai mencapai data yang stabil. Jika terjadi perubahan target behavior pada fase intervensi setelah dibandingkan dengan baseline, diasumsikan bahwa perubahan tersebut karena adanya pengaruh dari variabel independen atau intervensi.

Pelaksanaan Peneltian melalui tahap-tahap (1) tahap pemilihan subyek penelitian. Dalam penelitian ini peneliti mengamati satu kelompok subyek yang berjumlah 36 siswa kelas VII-I SMP Negeri 3 Kediri dengan cara menyebarkan angket, kemudian diambil 2 subyek dengan jumlah skor angket paling tinggi yang mengindikasikan subyek mengalami glossophobia tinggi. Hasil dari pembagian angket tersebut dikomunikasikan dengan Guru Bimbingan dan Konseling (BK) sekaligus wawancara terhadap teman sekelas subyek, dan hasil wawancara pun menunjukkan bahawa 2 subyek tersebut memang mengalami permasalahan glossophobia, (2) tahap pengukuran Baseline. Tahap pengukuran baseline dilakukan dengan observasi langsung terhadap dua subyek yang telah ditentukan. Fase baseline diukur selama 3 sesi, dimana masing-masing sesi dilakukan observasi selama 40 menit. Hasil pengukuran baseline menujukkan trend kedua subyek tersebut stabil. Hal ini didukung dengan hasil wawancara dengan kedua subyek tersebut. Selain pertimbangan tersebut, subyek penelitian berfokus pada 2 siswa agar pemberian tindakan penelitian bisa lebih fokus dan hasilnya lebih maksimal dengan pengambilan subyek yang sedikit. Jadi, subyek dalam penelitian ini adalah dua siswi kelas VII-I SMP Negeri 3 Kediri yang mengalami glossophobia paling tinggi, (3) tahap intervensi. Pada tahap intervensi, peneliti melaksanakan hipnoterapi teknik regression therapy sebagai upaya untuk mengatasi glossophobia siswa. Proses ini dilakukan selama 4 sesi dengan masingmasing waktu 20-30 menit untuk menemukan perubahan penurunan glossophobia yang dirasakan. Setiap proses intervensi selesai, subyek diberikan angket glossophobia yang pernah diisi sebelum diberikan intervensi. Pengisian angket ini bertujuan untuk mengukur sejauh mana perubahan yang terjadi terhadap penurunan glossophobia setelah diberikan intervensi, dan (4) tahap penulisan laporan. Tahap pembuatan laporan penelitian adalah tahap terakhir dari kegiatan penelitian.

\section{HASIL DAN PEMBAHASAN}

Data-data penelitian diperoleh melalui angket, observasi, dan wawancara, selanjutnya dianalisis menggunakan statistik deskriptif sederhana sesuai saran Sunanto, dkk (2005), bahwa teknik analisis data untuk jenis penelitian subyek tunggal dilakukan melalui tiga langkah, yakni: (1) yang dilakukan melalui tiga hal utama yaitu, pembuatan grafik, penggunaan statistik deskriptif, dan menggunakan analisis visual. Analisis yang dilakukan melalui dua langkah yaitu, analisis dalam kondisi, dan analisis antar kondisi. Komponen analisis visual untuk dalam kondisi meliputi enam komponen, yaitu: (1) panjang kondisi, adalah jangka waktu untuk melihat tingkat kestabilan baseline atau intervensi, (2) estimasi kecenderungan arah, menjelaskan perubahan setiap data dari sesi ke sesi, (3) kecenderungan stabilitas, tingkat kestabilan perubahan yang terjadi pada fase baseline atau intervensi, (4) jejak data, menggambarkan data dari kondisi baseline atau intervensi meningkat atau menurun, (5) level stabilitas dan rentang, rentang kestabilan fase baseline dan intervensi dan (6) level perubahan, menggambarkan peningkatan atau penurunan fase baseline atau intervensi. 
Sedangkan analisis visual untuk antar kondisi ada lima komponen, yaitu: (1) jumlah variabel yang diubah, menunjukkan jumlah target behavior yang ingin dirubah, (2) perubahan kecenderungan dan efeknya, melihat perubahan kondisi setelah intervensi, (3) perubahan stabilitas, kestabilan kondisi baseline ke kondisi intervensi, (4) perubahan level, menunjukkan perubahan target behavior setelah diberikan intervensi, dan (5) data overlap, perubahan data yang tidak stabil.

Melalui langkah-langkah analisis di atas, hasilnya dilaporkan sebagai berikut:

Berdasarkan hasil observasi dan angket kedua subyek mengalami perubahan tingkat penurunan glossophobia. Hal tersebut dapat dibuktikan dengan analisis data yang dilakukan peneliti yaitu: Analisis visual dalam kondisi subyek DZ. (1) Dilihat dari grafik analisis visual dalam kondisi subyek DZ pada fase baseline (A) dan fase intervensi (B), pada fase baseline (A) sesi 1 DZ memperoleh skor $78 \%$, sesi $273 \%$ dan sesi $375 \%$. Kemudian pada fase intervensi (B) sesi $1 \mathrm{DZ}$ memperoleh skor $65 \%$, sesi ke 2 memperoleh $67 \%$, sesi ke $355 \%$ dan sesi ke 4 54\%. Hal ini menunjukkan bahwa DZ mengalami penurunan tingkat glossophobia, (2) Estimasi kecenderungan arah pada fase baseline (A) menurun, pada fase intervensi (B) kecenderungan arahnya menurun atau ada perubahan yang positif, (3) Kecenderungan stabilitas pada fase baseline (A) stabil sebab persentasenya mencapai $100 \%$, pada fase intervensi (B) stabilitasnya tidak stabil (variabel) yaitu $50 \%$. Sunanto dkk. (2005) kecenderungan stabilitas ini memakai pedoman jika persentase stabilitas sebesar 85\%-90\% maka dikatakan stabil. Semakin sedikit persentase stabilitasnya semakin baik. Berdasarkan grafik secara keseluruhan menunjukkan penurunan tingkat glossophobia, akan tetapi berdasarkan hitungan kecenderungan stabilitas dikatakan tidak stabil, (4) Jejak data pada fase baseline (A) menurun atau dikatakan ada perubahan, pada fase intervensi (B) kecenderungan arah juga menurun, (5) Level stabilitasnya pada fase baseline (A) lebih stabil disbanding fase intervensi (B). Pada fase baseline (A) datanya stabil dengan level dan rentang 69,48- 81,18, sedangkan pada fase intervensi (B) dengan rentang 55,22 - 65,28 memiliki level stabilitas yang tidak stabil yang artinya menunjukkan perubahan ke arah yang positif, untuk menentukan level stabilitas dan rentang ini telah dihitung pada kecenderungan stabilitas, dan (6) Level perubahannya positif $(+)$.

Analisis dalam kondisi subyek SS. (1) Dilihat dari grafik analisis visual dalam kondisi subyek SS pada fase baseline (A) dan fase intervensi (B), pada fase baseline (A) sesi $1 \mathrm{SS}$ memperoleh skor $77 \%$, sesi 2 $78 \%$ dan sesi $378 \%$. Kemudian pada fase intervensi (B) sesi $1 \mathrm{SS}$ memperoleh skor $64 \%$, sesi ke 2 memperoleh $51 \%$, sesi ke 3 $45 \%$ dan sesi ke 4 44\%. Hal ini menunjukkan bahwa SS mengalami penurunan tingkat glossophobia, (2) Estimasi kecenderungan arah pada fase baseline (A) meningkat, pada fase intervensi (B) kecenderungan arahnya menurun atau ada perubahan yang positif, (3) Kecenderungan stabilitas pada fase baseline (A) stabil sebab persentasenya mencapai $100 \%$, pada fase intervensi (B) stabilitasnya tidak stabil (variabel) yaitu $50 \%$. Sunanto dkk. (2005) kecenderungan stabilitas ini memakai pedoman jika persentase stabilitas sebesar 85\%-90\% maka dikatakan stabil. Semakin sedikit persentase stabilitasnya semakin baik. Berdasarkan grafik secara keseluruhan menunjukkan penurunan tingkat glossophobia, akan tetapi berdasarkan hitungan kecenderungan stabilitas dikatakan tidak stabil, (4) Jejak data pada fase baseline (A) meningkat, pada fase intervensi (B) kecenderungan arah menurun atau dikatakan ada perubahan, (5) Level stabilitasnya pada fase baseline (A) lebih stabil disbanding fase intervensi (B). Pada fase baseline (A) datanya stabil dengan level dan rentang 71,82-83,52, sedangkan 
pada fase intervensi (B) dengan rentang 46,2 - 55,8 memiliki level stabilitas yang tidak stabil yang artinya menunjukkan perubahan ke arah yang positif, untuk menentukan level stabilitas dan rentang ini telah dihitung pada kecenderungan stabilitas, dan (6) Level perubahannya positif $(+)$.

Analisis Antar Kondisi. Subyek DZ. (1) Perubahan kecenderungan arah tingkat glossophobia DZ menuju pada perubahan yang positif karena dapat dilihat pada grafik yang arah trendnya menurun. Perubahan DZ dikatakan tidak signifikan karena terdapat data point dalam intervensi yang meningkat. Hal ini dikarenakan DZ kurang terbuka terhadap peneliti. Selain itu DZ memang tergolong anak yang pendiam, (2) Perubahan kecenderungan stabilitas pada fase baseline (A) stabil, sedangkan pada fase intervensi (B) tidak stabil. Ini dapat dilihat pada analisis dalam kondisi dimana persentase pada fase baseline (A) 100\%, sedangkan pada fase intervensi (B) $50 \%$. Kecenderungan stabilitas ini semakin tidak stabil semakin baik, karena semakin data stabil berarti tidak menunjukkan perubahan yang signifikan, (3) Perubahan level pada DZ adalah positif, dan (4) Sedangkan pada persentase overlap juga baik yaitu $0 \%$. Persentase overlap ini dikatakan baik sebab semakin kecil persentase overlap semakin baik pengaruh intervensi.

Analisis antar kondisi subyek SS. (1) Perubahan kecenderungan arah tingkat glossophobia SS menuju pada perubahan yang positif karena dapat dilihat pada grafik yang arah trendnya menurun. Perubahan SS tergolong stabil karena data pointnya selalu menurun, hal ini dikarenakan SS terbuka terhadap peneliti dan mempunyai keinginan penuh untuk merubah kondisinya, (2) Perubahan kecenderungan stabilitas pada fase baseline (A) stabil, sedangkan pada fase intervensi (B) tidak stabil. Ini dapat dilihat pada analisis dalam kondisi dimana persentase pada fase baseline (A) $100 \%$, sedangkan pada fase intervensi (B) $50 \%$. Kecenderungan stabilitas ini semakin tidak stabil semakin baik, karena semakin data stabil berarti tidak menunjukkan perubahan yang signifikan, (3) Perubahan level pada SS adalah positif, dan (4) Sedangkan pada persentase overlap juga baik yaitu $0 \%$. Persentase overlap ini dikatakan baik sebab semakin kecil persentase overlap semakin baik pengaruh intervensi.

\section{SIMPULAN DAN SARAN}

Berdasarkan keseluruhan proses penelitian ini dapat disimpulkan bahwa penerapan hipnoterapi teknik regression therapy efektif untuk mengatasi penderita glossophobia siswa. Hal ini dibuktikan dengan trend dari grafik kedua subjek menurun yang menunjukkan perubahan positif dimana glossophobia subjek juga mengalami penurunan.

Untuk itu, disarankan bagi guru BK dan konselor sekolah dapat menggunakan hipnoterapi teknik regression therapy untuk menangani siswa yang menderita glossophobia. Bagi peneliti lanjutan, disarankan untuk meneliti dengan jangkauan subyek dan lokasi yang lebih besar.

\section{DAFTAR PUSTAKA}

Arikunto, Suharsimi. 2014. Prosedur Penelitian (cetakan kelima belas). Jakarta: PT. Rineka Cipta.

Atkinson, Rita L. dkk. 2005. Pengantar Psikologi. Jakarta: Erlangga.

Atrup, 2014. "Pengembangan Model Konseling Integratif Berbasis Hipnoterapi Sebagai Upaya Peningkatan Peran Konselor di Sekolah", Prosiding Seminar Nasional Bimbingan dan Konseling, Pemberdayaan Bimbingan dan Konseling Sekolah, Surabaya: Prodi BK-Unesa, p. 16-32

Atrup; Setyawati, S. P; dan Agan, S. 2015. "Model Konseling Integratif Berbasis Hipnoterapi dalam 
Memecahkan Masalah Traumatik", Laporan Hasil Penelitian Hibah Bersaing Tahun Pertama, Kediri: LPPM UN PGRI Kediri.

Atrup dan Setyawati, S. P. 2016a. "Model Konseling Integratif Berbasis Hipnoterapi dalam Memecahkan Masalah Traumatik", Laporan Hasil Penelitian Hibah Bersaing Tahun Kedua, Kediri: LPPM UN PGRI Kediri.

Atrup dan Setyawati, S. P. 2016b. "Model Konseling Integratif Berbasis Hipnoterapi dalam Memecahkan Masalah Traumatik Bencana", Prosiding Seminar Bimbingan dan Konseling 2016, Optimalisasi Peran Konselor Melalui Pemanfaatan Berbagai Pendekatan dan Terapi dalam Pelayanan Konseling, Padang: UNP Padang, p. 10-18

Atrup dan Setyawati, S. P. 2016c. "Model Hipotetik Konseling Integratif Berbasis Hipnoterapi dalam Memecahkan Masalah Traumatik", Proceeding International Conference and Workshopon School Counseling, The Role of School Counselors in Dealing with Students with Special Needs in Inclusive Shools, Yogyakarta: Universitas Sanata Dharma, p. 144154.

Atrup; Setyawati, S. P. dan Putra, A. D. 2016d. "Hypnocounseling: Implementasi Model Konseling Integratif Berbasis Hipnoterapi dalam Memecahkan Masalah Traumatik Konseli”, Buku Panduan, Kediri: LPPM UN PGRI Kediri.

Corey, G. 2013. Teori dan Praktek Konseling \& Psikoterapi, Edisi Ketujuh. Terjemahan E. Koswara. Bandung: PT Refika Aditama.
Creswell, John. 2015. Riset Pendidikan, Edisi Pertama.Terjemahan Drs Helly Prajitno Soetjipto, M.A., Dra. Sri Mulyantini Soetjipto. Yogyakarta: Pustaka Belajar.

Daryanto. 2011. Ilmu Komunikasi. Bandung: PT Sarana Tutorial Nurani Sejahtera.

Fatma, Anne dan Sri Ernawati. 2012. Pendekatan Perilaku Kognitif Dalam Pelatihan Keterampilan Mengelola Kecemasan Berbicara Di Depan Umun. Jurnal Psikologi, (Online), I (1): 39-65, tersedia: http://www.scribd.com/doc/247554 777/PENDEKATAN-PERILAKUKOGNITIF-DALAMPELATIHAN-KETERAMPILANMENGELOLA-KECEMASANBERBICARA-DI-DEPANUMUM-doc\#scribd, diunduh pada 10 Nopember 2016.

Gunawan, W. Adi. 2012a. Hypnosis The Art of Subconscious Communication (cetakan keenam). Jakarta: PT Gramedia Pustaka Utama.

Gunawan, W. Adi. 2012b. Hypnotherapy The Art of Subconscious Restructuring (cetakan kelima). Jakarta: PT Gramedia Pustaka Utama.

Haryanthi, Luh Putu Suta dan Nia Tresniasari. 2012. "Efektivitas Metode Terapi Ego State dalam Mengatasi Kecemasan Berbicara di Depan Publik pada Mahasiswa Fakultas Psikologi UIN Syarif Hidayatullah Jakarta". Jurnal Psikologi, (Online), 14 (01): 32-40, tersedia:

http://www.google.co.id/url?sa=t\&r $\mathrm{ct}=\mathrm{j} \& \mathrm{q}=\&$ esrc $=\mathrm{s} \&$ source $=$ web $\& \mathrm{~cd}$ $=1 \& \mathrm{cad}=\mathrm{rja} \& u a c t=8 \& \mathrm{ved}=0 \mathrm{CB} 4 \mathrm{Q}$ 
FjAA\&url=http $\% 3 \mathrm{~A} \% 2$ Fjournal.un air.ac.id $\% 2$ FfilerPDF $\% 2$ Fartikel $\% 2$ 5204-14-

1.pdf\&ei $=3 \mathrm{pJkVfr} 0 \mathrm{D} 8 \mathrm{SVuASsvoP}$ YBQ\&usg=AFQjCNECIIYZJDTn 79T2AyXYBIW9zXHDZw, diunduh 7 Desember 2016.

Hunter, C. Roy. 2015. Seni Hipnoterapi. Jakarta: PT Indeks.

Kartono, Kartini. 2000. Hygiene Mental. Bandung: Mandar Maju.

Khan, Fahad.dkk. 2015. "Glossophobia among Undergraduate Students of Government Medical Colleges in Karachi”. International Journal of Research, (Online), 2 (1): 109-115, tersedia:

http://internationaljournalofresearch .org/index.php/ijr/articla/view/1297 1226, diunduh 7 Desember 2016.

Komalasari, G., Wahyuni, E., \& Karsih. 2011. Teori dan Teknik Konseling. Jakarta: PT. Indeks.

Nevid. S Jeffrey, Ratus. A Spencer dan Greene Beverly. 2003. Psikologi AbnormalJilid 2, Edisi Kelima. Jakarta: Erlangga.

Nuryono, Wiryo. 2016. "Penerapan Konseling Naratif untuk Mengurangi Tingkat Glossophobia Siswa Kelas X SMAN 13 Surabaya". Jurnal BK UNESA, 6 (1). (Online), tersedia: www.ejournal.unesa.ac.id, diunduh 10 Nopember 2016.

Ratnasari, Devi. 2012. "Penggunaan Konseling Kelompok Dengan Kombinasi Strategi Reframing dan Self Monitoring untuk Menurunkan Tingkat Kecemasan Berbicara Di Depan Umum". Jurnal BK UNESA, 2 (1). (Online), tersedia: www.ejournal.unesa.ac.id, diunduh 10 Nopember 2016.

Sunanto, Juang dkk.2005. Pengantar Penelitian dengan Subyek Tunggal.Criced University of Tsukuba.(Online). Tersedia di: www.ktiguru.net/Juang+Sunanto/Lamprian-1_SSR.pdf, diunduh pada 18 Nopember 2016.

Sugiyono. 2015. Metode Penelitian Kuantitatif, Kualitatif, dan $R \& D$ (cetakan kedua puluh dua). Bandung: Alfabeta.

Tse, Yau-hau. Andrew. 2012. Glossophobia of University Students in Malaysia. Journal Asian Social Science, (Online), 2 (11): 2061-2073, tersedia:

http.//umpir.ump.edu.my/2926/, diunduh pada 7 Desember 2016.

Werhadiantiwi, Pradita Arisgi. 2014. "Penerapan Konseling Kelompok dengan Teknik Self Instruction untuk Mengurangi Tingkat Glossophobia pada Siswa Kelas XI IPS-1 Di SMA Negeri 1 Gedangan". Jurnal BK UNESA, 4 (3). (Online), tersedia: www.ejournal.unesa.ac,id, diunduh 10 Nopember 2011 